\title{
Multiple myeloma with multilobated plasma cell nuclei
}

\author{
Çok çekirdekli plazma hücreli Multipl Miyelom
}

\author{
Nergiz Erkut ${ }^{1}$, Ümit Çobanoğlu ${ }^{2}$, Mehmet Sönmez ${ }^{1}$ \\ 'Department of Haematology, School of Medicine, Karadeniz Technical University, Trabzon, Turkey \\ ${ }^{2}$ Department of Pathology, School of Medicine, Karadeniz Technical University, Trabzon, Turkey
}

A 61-year-old male patient was admitted to our hospital with backache and fatigue. Physical examination was normal, except for pallor. Laboratory results at initial evaluation were as follows: hemoglobin: $105 \mathrm{~g} \mathrm{~L}$; hematocrit: 0.31\%; white blood cell (WBC) count: $6.3 \times 10^{9} \mathrm{~L}$; platelet count: $200 \times 10^{9} \mathrm{~L}$; blood urea nitrogen (BUN): $22.1 \mathrm{mmol} \mathrm{L}$; creatinine: $477.3 \mu \mathrm{mol} \mathrm{L}$; calcium: $2.8 \mathrm{mmol} \mathrm{L}$; total protein: $74 \mathrm{~g}$ L; albumin: $43 \mathrm{~g} \mathrm{~L}$; erythrocyte sedimentation rate (ESR): $44 \mathrm{~mm} \mathrm{~h}^{-1}$. A monoclonal spike was present on protein electrophoresis. Protein studies (by nephelometry) showed a kappa light chain of $5.97 \mathrm{~g} \mathrm{~L}$ (reference range: 1.7-3.7 g L) and low levels of IgG, IgM, and IgA ( $8.84 \mathrm{~g} \mathrm{~L}, 0.30 \mathrm{~g} \mathrm{~L}, 0.53 \mathrm{~g} \mathrm{~L}$, respectively). Beta 2 microglobulin was $1.2 \mathrm{mg} \mathrm{dL}$ (reference range: $0.07-0.19 \mathrm{mg} \mathrm{dL}$ ). Urine immunoelectrophoresis showed that the patient had a kappa monoclonal light chain. Bone X-rays showed multiple osteolytic lesions. The bone marrow aspirate and biopsy specimen morphology showed infiltration by atypical and multilobated plasma cell nuclei (Figures 1 and 2). The bone marrow biopsy specimen stained positive with CD138 (Figure 3).

Multiple myeloma with multinucleated plasma cells is a rare morphological variant, which usually presents with light chain expression, and is charac-

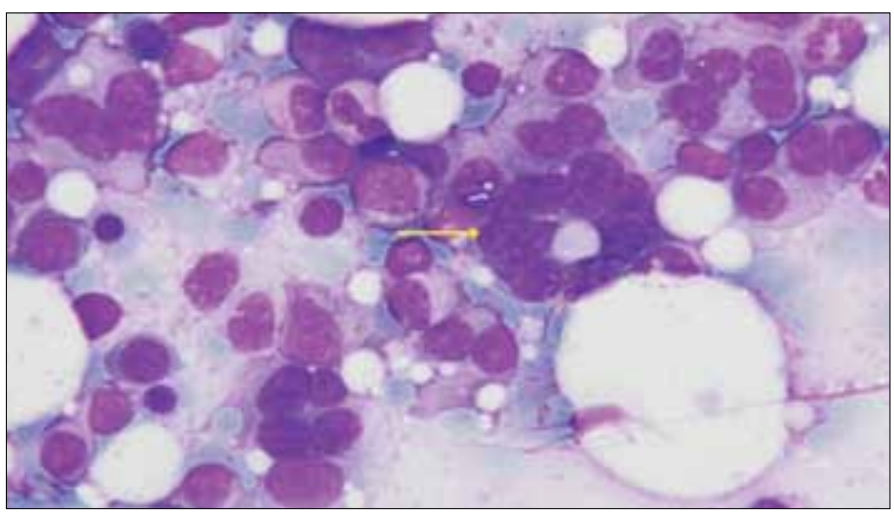

Figure 1. Atypical and multinucleated plasma cell infiltration in bone marrow aspirate

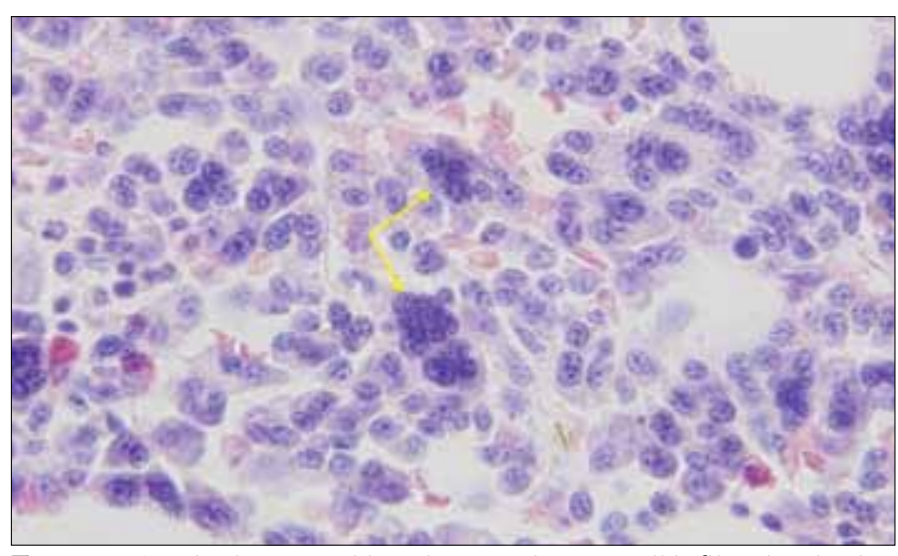

Figure 2. Atypical and multinucleated plasma cell infiltration in the bone marrow biopsy specimen

Address for Correspondence: Dr. Mehmet Sönmez, Department of Haematology, School of Medicine, Karadeniz Technical University, 61080 Trabzon, Turkey Phone: +90 4623775848 Fax: +90 4623280704 E-mail: mesonmez@yahoo.com 


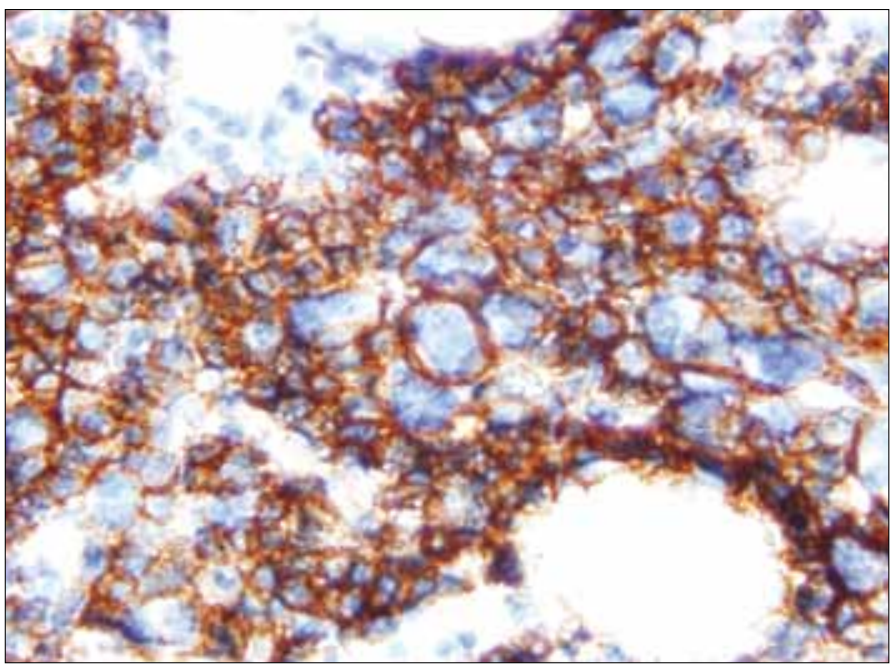

Figure 3. Kappa light chain-positive bone marrow biopsy specimen terized by an aggressive course and resistance to conventional chemotherapy [1,2]. Informed consent was obtained from the patient.

\section{Conflict of interest statement}

The authors of this paper have no conflicts of interest, including specific financial interests, relationships, and/or affiliations relevant to the subject matter or materials included.

\section{References}

1. Fonseca R, San Miquel J. Prognostic factors and staging in multiple myeloma. Hematol Oncol Clin North Am. 2007;21:1115-40.

2. Kyle RA, Rajkumar SV. Criteria for diagnosis, staging, risk stratification and response assessment of multiple myeloma. Leukemia. 2009;23:3-9. 